\title{
Genesis of Public Broadcaster in Post-Soviet Society. Lithuanian Case
}

\author{
Zygintas Peciulis \\ Faculty of Communication, Vilnius University, 7 Maironio str., LT-01124 Vilnius, Lithuania \\ Corresponding author's e-mail address: zygintap@takas.lt
}

\begin{abstract}
The goal of the research was to analyse the development of the idea of the public service broadcasting (PSB) in Lithuania as one of Post-Soviet countries that restored its independence in 1990. The Lithuanian case serves in revealing the great variety of ways to interpret the idea of the PSB, the possibilities to manipulate various notions, and the way the fate of the PSB can be affected by politicians and competing business groups.

In this research we distinguished the following stages of the PSB concept formation in Lithuania: the first debates (the development of legislative basis), and attempts of influence - the socalled depoliticisation, decommercialisation, and optimization. In order to achieve it, we analysed the Lithuanian legislation and its amendments, parliamentary discussions, and press publications. We also compared the Lithuanian PSB concept with the Western perception.

It was concluded that despite of the official declarations about further limiting the interference with the national service broadcaster, there actually were the attempts of influence and politicisation. Politicisation by depoliticising. In pursuit of changing the Lithuanian Radio and Television (LRT) management the procedure of LRT Council formation was changed in 1996-1997: representatives were delegated by 15 creative and public organisations. The principles of public organisations selection have been criticised. Politicisation by de-commercialising. In 2000-2002, the LRT was criticised because of its commercialisation and non-performance of its mission. It was intended to develop a special funding system whereby the LRT should submit the Seimas with a funding plan and evidences justifying that the anticipated programmes are in compliance with the national mission. Introduction of such amendments could pose a risk of direct political interference with the LRT management and formation of the programme content. Politicisation by optimising. In 2009-2010 the attempts were made to radically reform the LRT management. The criticism related to linkage of the LRT Council members mandate with the political calendar, possibility of recalling the Council members by the delegating institutions and organisations, and the right of the Seimas Committee to approve or reject the strategy of the LRT programming. In 2014, a new financing model of the LRT has been developed, following which the LRT in 2015 discontinued broadcasting the commercial ads (except for certain established cases). The LRT financing is known in advance and calculated on the basis of the budget revenue and excise duty collection results of a preceding calendar year.
\end{abstract}

KEYWORDS: public service broadcasting, Lithuanian Radio and Television, LRT, radio, TV, soviet propaganda. 


\section{Генезис громадського мовника в пострадянському суспільстві. Литовський приклад}

Зигінтас Песіліус, Інститут журналістики факультету комунікації Вільнюського університету, nрофесор, Dr. Habil.

\section{Резюме}

Метою дослідження було проаналізувати розвиток ідеї суспільного мовлення в Литві як одній $з$ пострадянських країн. Литовський випадок є показовим для демонстрації різних інтерпретацій ідеї суспільного мовлення, маніпуляцій відповідними поняттями і нормами, впливу на суспільне мовлення конкуруючих політичних та бізнес-груп.

У даному дослідженні ми виділили наступні етапи формування концепції суспільного мовлення в Литві: перші дебати (розвиток законодавчої бази), а також спроби впливу - так звані «деполітизація», «декомерціалізація» та «оптимізація». Було проаналізовано відповідне законодавство Литви і поправки до нього, парламентські обговорення, публікацій в пресі. Ми також порівняли литовську концепцію суспільного мовлення із західним тлумаченням.

Дослідження дало підстави дійти висновку, що, попри офіційні заяви про обмеження втручання до роботи національної служби мовлення, мали місце спроби впливу і політизації іiі діяльності. «Деполітизація»: в 1996-1997 рр. був змінений порядок формування Ради Литовського радіо і телебачення (LRT), до якої було делеговано представників 15 творчих i громадських організацій. Принципи відбору громадських організацій зазнали критики. «Декомерціалізація»: в 2000-2002 pp. LRT критикували за надмірну комерціалізацію і не виконанні своєї державної місії. Було вирішено розробити спеціальну систему фінансування, за якою LRT мала представляти Сейму план фінансування та свідоцтво відповідності запланованих програм державній місії. Введення таких змін могло становити небезпеку прямого політичного втручання у формування змісту програм. «Onтимізація»: в 20092010 рр. були зроблені спроби радикального реформування управління LRT, які критикувалися за пов'язування мандата членів Ради LRT з політичним календарем, за можливість відкликати членів Ради установами та організаціями, які їх делегували, а також за права Комітету Сейму схвалювати або відхиляти стратегію мовлення LRT. У 2014 р. була розроблена нова модель фінансування LRT, після чого з 2015 р. LRT припинила трансляцію комерційної реклами (окрім деяких визначених випадків). Фінансування LRT розраховується заздалегідь на основі доходів бюджету і акцизного збору за попередній календарний рік.

Ключові слова: суспільне мовлення, Литовське радіо і телебачення, LRT, радіо, телебачення, радянська пропаганда.

Зигинтас П. Генезис общественного вещателя в постсоветском обществе. Литовский пример.

Резюме. Целью исследования было проанализировать развитие идеи общественного вещания в Литве как одной из постсоветских стран. Литовский случай показателен для демонстрации различных интерпретаций идеи общественного вещания, манипуляций соот- 
ветствующими понятиями и нормами, влияния на общественное вещание конкурирующих политических и бизнес-групп. В исследовании выделены следующие этапы формирования концепции общественного вещания в Литве: первые дебаты (развитие законодательной базы), а также попытки воздействия - т.зв. «деполитизация», «декоммерциализация» и «оптимизация». Исследование дало основания сделать вывод, что, несмотря на официальные заявления об ограничении вмешательства в работу национальной службы вещания, имели место попытки влияния и политизации её деятельности.

Ключевые слова: общественное вещание, Литовское радио и телевидение, LRT, радио, телевидение, советская пропаганда.

\section{Introduction}

The idea of Public Service Broadcasting (PSB) is associated with the Greek agora and the Roman forum. It is a modern evolution of the idea of a public space and a citizens' forum $[1 ; 2$; 3]. It is the continuation of public services that serve the citizens' needs (water supply, gas, electricity, police, medical aid), known since the Medieval times as utilitas publica [4; 5]. The PSB emerges as an alternative to state and commercial media models. In the beginning of the 20th century, the subordinate press, developed under absolute monarchies, is transformed into propaganda media of fascist and communist states. The free media, which appeared in the UK, France, and the USA in the end of the 18th c., develops the idea of the freedom of the press and the fourth power [6;7]. In the 20th c., this concept splits into the Anglo-Saxon one (the liberal commercial US audiovisual broadcasting model or the mixed competitive audiovisual market of Great Britain) and the continental one (the Western European PSB monopoly) [8; 9; 10; 11].

In Italy, Sweden, and Switzerland it is private companies that launch radio and TV broadcasts, while in France and Belgium these are private and state broadcasters [12]. For the sake of political compromise, in Great Britain the concept of PSB emerges. The Crawford Report, published in 1926 [13], stated that the radio cannot be put into private hands as its significance in society is too great. In order to avoid the political influence of the governing majority, political parties agreed to design an audiovisual broadcasting system that would ensure a safe distance between the government and the broadcaster, and serve citizens' interests rather than those of political powers or consumers [14]. The essence of the concept was that the PSB was to be governed and funded by the citizens. The independent management of the PSB was to be ensured by the boards of plenipotentiaries (delegated by institutions and public organizations) or appointees (appointed by the Parliament, the president, the government). Independent financing was to be ensured by a subscription fee paid by radio and TV receiver holders. The following principles of the PSB are mentioned the most frequently: the institutional ones (the citizens' will is expressed via public management boards), the legal ones (including certain obligations regarding program content as well as prerogatives such as secure financing, priority in distributing broadcasting frequencies), and the ideological ones (the broadcaster mission) $[15 ; 16 ; 17 ; 18]$. The main goals of the PSB are considered to be shaping national identity, serving the needs of various social groups, and promoting democracy $[19 ; 20]$.

The British PSB concept of post-war consensus [21] spread across Western Europe after the World War II, and in Eastern and Central Europe in the 1990s. When adapting it, different models of forming and financing management institutions (subscription fee, budgetary subsidies, advertising) were opted for. The European Broadcasters Union (EBU) does not indicate a specific managerial and financing regulation. It is recommended for management institutions to ensure independent editorial policy in a PSB, and financing should be sufficient for fulfilling its 
mission. Once the Western European audiovisual market was liberalized and the PSB monopoly abolished in the 1990s, the issue of broadcasting commercials gained acute relevance. The PSB was accused of selling the same product twice as the programmes were paid for via subscription fee or state subsidies as well as through advertising revenues [22].

The idea of the PSB raises controversial attitudes. According to J. Bourdon, the PSB demonstrates how a religious or police-based state evolves into a state of care and intercession [23], P.Legendre sees the noble and generous concept as a form of state renunciation [24]. However, S. De Proost believes that the PSB is nevertheless characterised by the logic of state monopoly, allowing to politicize the management and preserving the priority right to airtime for politicians [5]. G. Murdock doubts whether commercial broadcasters in the US have merited the democracy less than the European public ones [25]. Historic experience shows that the PSB model leaves leeway for influence from politicians [26]. The most frequently mentioned cases include the efforts of the French Communist and Gaullist alliance to control the media, the influence of the Italian Christian Democratic Party on the television, and the Italian and Dutch aim to provide public TV channels for political party influence [27; 28; 29].

\section{Research Methods}

A glance at the development of the PSB concept reveals its variety and problematic nature. Our goal was to analyse the development of the idea of the PSB in Lithuania as one of PostSoviet countries that restored its independence in 1990. The Lithuanian case serves in revealing the great variety of ways to interpret the idea of the PSB, the possibilities to manipulate various notions, and the way the fate of the PSB can be affected by politicians and competing business groups. We brought forward an assumption that the variety of interpretations of the PSB prevents the establishment of full independence from political influences. The Lithuanian case shows that the political pendulum law applies as attempts to destabilize the operation of the PSB usually correspond to the political calendar.

We distinguished the following stages of the PSB concept formation in Lithuania: the first debates (the development of legislative basis), and attempts of influence (the so-called depoliticisation, decommercialisation, and optimization).

In order to achieve it, we analysed the Lithuanian legislation and its amendments, parliamentary discussions, and press publications. We also compared the Lithuanian PSB concept with the Western perception.

\section{Results and Discussion}

The First Debate: Development of Legislative Framework

The television that appeared in Lithuania (1957) while it was incorporated into the composition of the Soviet Union becomes a propaganda tool for the governing Communist Party to achieve its goals. The managers of the Lithuanian Radio and Television (LRT) are appointed and controlled by government structures controlled by the Communist Party. Television is more suitable for ideological purposes than other means of mass media and propaganda: it is accessible and understandable to all. The aims of the state broadcaster are revealed in the goals that are set out. Public political programmes should shape the materialistic outlook in ordinary working people, instil ideas of Soviet patriotism and proletarian internationalism, and mobilize collectives in order to solve economic and social tasks indicated by the party. Economic programmes should talk about work organization, socialist racing, rationalisers' movement, increasing work productivity, and improving product quality [30]. Ideological goals are also set out for programmes of culture and art, as well as children's and youth programmes. They determine the size of the pro- 
gramme, the ideas proclaimed, and the standards promoted. The LRT served the dissemination of basic ideological postulates for three decades.

Since the outset of the resurgence (Atgimimas), with establishment in 1988 of the reform movement Sajūdis, discussions started on the public service broadcaster (PSB) along Western lines, with its independent control and financing, and representing interests of different society layers. The public sphere concept has been perceived as the social interaction arena, a citizens' forum where arguments are made and public opinion is shaped, and political decisions are built by a democratic state $[1 ; 3]$.

Political changes in Lithuania coincided in time with deregulation and de-monopolization of the Western European audio-visual sector launched in the mid-1980s. Legalisation of commercial broadcasters led to identity crisis experienced by the public sector of the Western Europe caused by competition, decreased level of audience, vague future prospects. Even though positions of the PSB in Europe have been shaken, such model for the post-communist states was a positive example of the freedom of expression and democratic management of media sector to be followed.

The attitude towards public broadcasting was determined by various aspects in Lithuania.

The politicians' strive to maintain influence. As the contradiction between the former Soviet and the new political government emerged, deliberations were ongoing on whether it was sufficient to simply shift the control of the radio and television from the hands of the previous (the mischievous) management into those of the new (the right) one. Tough economic situation and the need for public mobilization were used as arguments for the need to have a state broadcaster. As the governing majority changed after the election, efforts were present to reduce the influence of the previous majority.

Tension on the audiovisual market. Discussions on the PSB model were affected by the changed audiovisual market. In mid-1990s, commercial broadcasters emerge in Lithuania, which are associated to modernity and Western democracy, while the LRT is constantly reminded of its Soviet past. Commercial broadcasters aim at preventing the LRT from competing on the advertising market.

From the very beginning of independency in 1990, the soviet Lithuanian Radio and Television (LRT) was reorganized into an institution subordinate to the Supreme Council - Reconstituent Seimas. The LRT Managing Board appointed by the Seimas became the highest decision-making body of the Lithuanian Radio and Television. The Managing Board comprised of public representatives, nominated candidates to the position of Director General, for approval by the Seimas. The Managing Board had certain features incidental to the organizations that emerged in Great Britain ensuring that sufficient distance is maintained between a broadcaster and authorities.

The first Statute of Lithuanian Radio and Television established the essential democratic principles of the audio-visual broadcasting activities such as objectivity, democracy, the freedom of expression, editorial independence and freedom of conscience, pluralism (broadcasts are open to participation by people of different opinions and beliefs, and representatives of the variety of political parties, political and public participation movements, organizations, ethnic and religious communities). Discussion on the new status of the LRT emphasized the radio and television mission as an intermediary between the state and society, the authorities and citizens. Such provisions comply with the essential PSB regulating documents, namely the role emphasized by the European Parliament resolution of integrating society in political, economic, social and cultural life, considering the audio-visual organizations as the platform for discussions to express opinions and formulate public opinion [20]; the Treaty of Amsterdam with the EU Member States' confirmed commitment clarifying that the PSB system is directly related to the democratic, social and cultural needs of each society and the need to preserve media pluralism [31]; and social responsibility of a broadcaster as declared by the European Broadcasting Union (EBU) along with commitment to provide different and high-quality information assisting citizens to judge on the 
social policy and public life [32].

On the other hand, some indications of the state broadcaster also remained: the term of office of the LRT Management Board was linked to the political calendar, i.e. parliamentary elections and change of political authorities. LRT was obliged to promulgate official communique, present the official viewpoint of authorities on major issues of the state and public life. Members of the Parliament, heads of the subordinate state institutions, and members of the Government had the priority to use Lithuanian Radio and Television to discuss questions within their activities [33]. Such a duality, combination of sociality and statehood may be explained by discussions held in the Seimas. Some parliamentarians were of the opinion that a document defining the main PSB principles was premature, since it was relevant only for a democratic, free and independent state, which was not the case with Lithuania yet. Appealing to the special transitional stage in the state development, essentially, they have declared the principles of the state broadcaster, i.e. LRT is the state institution, and thus should take care of the state.

Supporters of the Western public model considered that such special position of the state was used as an attempt to justify pursuit of taking radio and television into somebody's own hands, and emphasized that democracy and publicity should not be forgotten while entrenching legitimacy of the statehood. Despite the challenging environment the supporters called for establishment of an independent organization, building the structures required for a normal democratic state [34]. Discussions on LRT financing were not in the meantime related to alternative sources, i.e. sufficient allocations were expected from the national budget. At the same time it was also acknowledged that in the context of a difficult economic situation such allocations would place a considerable burden on Lithuania, nevertheless the importance of radio and television for the state is understandable.

The first debate in the re-established independent Lithuania has disclosed the political polarization and open intentions of politicians to retain influence over the audio-visual media. During discussions on the candidacy of new LRT head, the representative of the new right-wing majority Gediminas Vagnorius has expressed the majority's view on taking over control of strategic entities, including LRT. He was asking whether anybody was aware of any examples when the political force having absolute majority in the parliament appoints to a leading position a person from the opposite political forces. "The fundamental revolutionary changes have taken place after the 11 March (author's note: Re-establishment of the State of Lithuania), and one should not think that everybody has accepted this fact. Elections of LRT manager is a stage in this political struggle. This is not a kind of professional competition; it is a pure political issue. (...) Of course, we can give this position to our opponents as in case of newspapers "Tiesa", "Komjaunimo tiesa", "Valstieciu laikrastis" or other state mass media. Perhaps giving radio and television away is also possible, and then practically everything will be (...) in the same hands, (...) that governed the Lithuanian Soviet Socialist Republic" [35]. It was thus formulated that the PSB is the same field of the governing majority interests as other seats of executive power.

With changes in composition of the Seimas after extraordinary elections (1992) the steps have been taken to change the composition of the LRT Managing Board (on the basis of LRT Statute establishing that the Seimas shall appoint the LRT Managing Board for the period of its mandate). Representative of the newly-formed opposition Andrius Kubilius has raised an issue of the overall need to form the Managing Board. Is it for the purpose of "laundering" responsibility of the direct television management? Escalating the issue, the Parliament member invoked the incompetence of LRT management and incapacity of the Managing Board to solve the problems of LRT [36]. Parliamentarian Vytautas Pleckaitis stated that the LRT Managing Board formed by the previous Seimas was dependant on the political landscape, with the same principle remaining in the new Seimas. He doubted whether the Seimas had competence in addressing the issue of the LRT Managing Board formation [36]. Chairman of the LRT Managing Board Laimonas Tapinas encouraged assuming the European concept of the public service broadcasting where radio and 
television are being considered not as an institution of the president, the parliament or the cabinet of ministers, but treated as an establishment accountable to the general public. On the other hand, he acknowledged the right of the parliament members to represent the citizens: members of the Seimas being representatives elected by the people express their will in forming the LRT leadership [36].

Despite the confrontation and different opinions, the fundamental changes of the Lithuanian media regulation were established in 1996 by Law on Provision of Information to the Public [37] and Law on the National Radio and Television [38]. The search for the most appropriate model to be applied in Lithuania was carried out by analysing media-regulating legislation of Great Britain, Sweden, Germany, Norway, France and other countries (analysed experience of 23 countries). New practice of developing such legislation has developed: involvement of public organizations (Radio and Television Association, Union of Journalists, Journalists' Society, Periodical Press Publishers' Association), international expertise (conclusions of foreign experts, European Broadcasting Union (EBU). To develop a new LRT management model no attempts have been made to copy a model of some specific country looking instead for a hybrid option.

Discussions on the law disclosed the political tension. One of the alternative law promoters Gintaras Babravičius spoke about strengthening, from 1992, of the control by the state institutions over the media while the state radio and television has been "totally controlled" [39]. Ongoing interference by politicians has also been emphasized by Laimonas Tapinas, LRT Director General, who resigned at the beginning of 1995. He told that "LRT hands were tied by idiotic laws, acts and norms, while the LRT has been treated as a political tool, some kind of a "blanket" which is considered by politicians as their own property, which is drawn by everybody to "cover" his own side. As per the Director General, the overall LRT existence, programmes made and broadcasted depend directly on the mercy of authorities. "If liked, you will receive higher budgeting, and if not, blame yourself" [40].

Law on Provision of Information to the Public and Law on the National Radio and Television, which came into effect in 1996, have formulated the principles of the LRT management. The highest decision-making body of the LRT now was the LRT Council formed for the period of three years and consisting of 13 members, with three of them appointed by the President, four members appointed by the Seimas, and six members delegated, as drawn by lot, by nine public organisations. The principle of rotation has also been introduced establishing that three years later those organisations that have not been in the composition of the Council in the first term of office could delegate their representatives. The Council was depoliticised, i.e. members of political parties had to suspend their membership until the end of their term of office. The LRT Council made a public call to fill the post of the Director General; until such time the LRT leader was appointed by the Seimas [37].

To reduce dependence of the LRT on the state budgetary allocations the other alternative forms of financing have been sought. Proposals were brought forward to collect funds for radio and television through increase of the tariffs per kilowatt of electricity or by introducing a subscription fee. Opinions divided. One part of the draft promoters were in favour of the alternative forms of financing, while the others remained committed to the budgetary allocations and revenues from the commercial advertising activities. It was decided to start collecting the subscription fee that could ensure independent financing of the broadcaster. During a transitional period the LRT had to be financed from the alternative sources: state budgetary allocations, subscription fee, revenues from sales of radio and television programmes, sponsorship and charity as well as advertising. With increasing proceeds from the subscription fee the budgetary allocations and the time intended for advertising had to be decreased. The time of the subscription fee introduction, its amount and collection procedure had to be established in a law on the LRT subscription fee; however such law has not been passed. The time of the subscription fee introduction was delayed until complete exclusion of this provision from the LRT Law. 
The topic of decommercialisation continuously appears on discussion agenda. European funding standards are aimed at, and ways to ensure constant and independent funding are searched for. The actions of the politicians keep a trace of the influence of commercial broadcasting lobbyists aiming to ban advertising on the LRT. Decommercialisation efforts are usually concealed with attempts to substantialize the goals and the mission of the PSB. However, eliminating advertisements without ensuring sufficient funding only increases subordination of the PSB further.

\section{Political Pendulum and Struggle over Influence on the LRT}

Politicisation by depoliticising. Despite the western model of the LRT management established in the Law on Provision of Information to the Public, political battle over influence on the LRT continued. The manifest tension was highlighted by the swing of the political pendulum after elections to the right or left. In 1996, with the end of the term of office of the left-wing majority, the procedure of the LRT Council formation was changed and new Director General was elected. The new right-wing majority after the elections treated such activities as an attempt of the losing political forces to keep their person in the LRT. Despite emphasis in the international documents of the necessity to ensure independence of a public service broadcaster from the political majority as well as the pursuit to avoid coincidence of the political calendar with the terms of office of the PSB management bodies $[41 ; 5]$, those who won the elections talked in a way as if such concept was not operating in Lithuania. It was claimed that every power comes with its own program and objectives that are supported by the large part of the nation who elected it. It has to establish institutions assisting in achievement of those objectives, while radio and television is one of such institutions [42].

In order to seize the influence over the LRT the PSB depoliticising was mentioned, stating that independence of the media from any political power is the first indicator of a democratic state maturity, prosperity and well-being [43]. In other words, it was decided that out of the combination of so-called authorised (representatives delegated by institutions and public organizations, professional and creative unions, the church, and academic community) and appointed (by the Parliament, the President and the Government) only the authorized shall be left, refusing delegation of the LRT members by the President and the Seimas. It was also decided to form the LRT managing body that would consist of the members from 15 creative and public organisations [38]. The critics of such decision were surprised at the criteria on the basis of which 15 public organisations have been selected out more than 500. The declared pursuit of depoliticisation has caused the crisis that de-stabilised the LRT activities. However, the political subtext has been disclosed by the legislative amendment specially intended for the existing situation establishing that upon formation of a new LRT Council the Director General shall resign.

Ensuring the financial independence of the LRT was suggested by employment of mixed sources, i.e. the subscription fee, state budgetary allocations, revenues from sales and issue of programmes, sponsorship and charity. It was also suggested establishing fixed LRT budget amounts $(0.4$ percent for television and 0.2 percent for radio from the total annual expenses of the state budget, each year reducing the budgetary allocations by the amount equal to the amount of the subscription fee and other revenues of the LRT received during a preceding calendar year). Furthermore, it was provided that the services of programmes broadcasting shall be paid for to the delivering entities directly from the state budget $(0.2$ percent from the total annual state budget expenditures). Implementation of the referred provisions would have been allowed making the LRT budgeting procedure on the basis of clear criteria, with the budget itself becoming forecastable and directly independent from the Government or the Seimas.

The opposition here noted the political subtext of de-politicisation. Some of them were afraid that the Seimas, as the LRT incorporator, would remain unrepresented and could not exercise any influence. The others took note that the suggested public organisations disclose the political mo- 
tives. "I cannot understand who allows you, at your sole will, grant the right to some organisations and no to other. Maybe you should allow doing it by organisations themselves?" criticised the Parliament member Vytenis Andriukaitis. Those who defended the idea of so-called depoliticisation assured that by opening new doors to the nation the democracy is being let in [43]. The political discussions evidenced that a certain part of the politicians were considering the LRT as the state broadcaster controlled by the ruling majority which is obliged to obey such ruling majority and become a propaganda tool for the executive power.

After some period of the LRT governance by the public organisations, in the beginning of 2000 the country returned back to the mixed model of the appointed and authorised members of the Council, i.e. 4 members for the term of six years appointed by the President, 4 members for the term of four years appointed by the Seimas ( 2 candidates suggested by the opposition), and 4 members for the term of two years delegated by the public organisations. Upon expiry of the Council member mandate, an institution that has appointed or delegated such member shall delegate a new member for the period of six years. The element of the executive power influence also remained, i.e. the Seimas each year was approving the LRT Council report. The rotation principle in the LRT Council has brought the stability into the LRT work; leaders of the LRT who previously were changing rather often now managed to work for the entire term of office. However, it is also true that such "formula" of the LRT Council formation has also been criticised, since two thirds of the LRT Council members were appointed on the political principle basis. The situation was also criticised because of the maximum term of office of 12 years threatening LRT stagnation [44]. The LRT management model formed in 2000 with some minor corrections and adjustments is still effective; however the period of 15 subsequent years evidences some manifest attempts (in 2002 and 2010) of changing.

Politicisation by de-commercialising. The Seimas of 2000-2004 returned back to the idea of the LRT de-politicisation and de-commercialisation with the declared pursuit of pulling the LRT out of the influence of politicians and business. According to the authors of the legislative amendment, since the 11 March 1990 the national radio and television as some kind of the Golan Heights has been the subject of speculations of all political forces [45]. However, the suggested amendments were increasing the interference of the Seimas not only in the finance allocation activities but the contents of the programmes as well. It was stated at that time that with increase of the commercial advertising the national radio and television is moving away from its mission of education and culture promotion. It was also concluded that less and less the LRT facilitates critical thinking, presenting less information on the European and global cultural diversity, the problems of modern society development and many other fundamental things. The LRT was being accused of becoming the re-allocator of the budgetary funds and seller of advertising time that does not apply any mission-related criteria to the programmes bought from producers. In the opinion of the LRT Law amendment initiators, the LRT has developed into the commercial broadcaster at the same time receiving huge allocations from the state. The question in this case was whether the state should continue funding the commercial channel setting itself apart from the intended mission overseen by the law. Seeking to readdress the unacceptable situation when the Seimas makes budgetary allocations without asking for advance justification of spending or a structural financing plan, which could evidence how the state allocations would be used. Development of a funding system was pursued to be used as a basis for the LRT to submit the Seimas not only with a financing plan but also with the evidences justifying that the forecasted programmes are in compliance with the national mission [45]. Provided such amendments were adopted, the Seimas would have taken the editorial control over the LRT.

Politicisation by optimising. In 2010-2011, the need was declared for strengthening the LRT Council function by establishing the positions of secretary and specialists of management, finance, and legal area. Jointly with optimisation-related recommendations the proposal was given to refuse the principle of rotation in the LRT Council, by linking the term of office of the Council 
members with the term of office of the institutions that delegate them. As if forgotten about the earlier discussion in Lithuania, the Western experience, and the principle of continuity, the initiators of amendments were surprised why the LRT Council has people delegated by the previous Seimas or the President. Discussions also returned back to the year 2002 and the issue of criteria formation then considered by the Seimas; this time the LRT Council had to establish the administration performance assessment indicators and formulate tasks to the Director General. Failure by the Director General to accomplish the targets within the established period may be subject to consideration of the issue of his dismissal. It was also suggested to simplify the dismissal procedure itself, i.e. by simple majority instead of two thirds of the votes. Adequacy of the criteria and targets formulated to the Director General had to be evaluated by the Seimas [46].

Political measures were followed by financial. Again it was attempted prohibiting the commercial advertising in the LRT without any provision of loss-compensating alternative sources. Since Lithuania at that time was already enjoying the membership in the European Union, conclusions on the initiated changes have been submitted by the European Law Department. The conclusions noted that despite the fact that prohibition of advertising does not contradict Audiovisual Media Services Directive, it had to be provided how absence of the advertising revenue would be compensated [47].

Pursuit of the part of politicians to change the LRT management and take over the PSB control faced public resistance. The LRT Council has addressed the Lithuanian society and international organisations. The Council stated that the LRT was working for a decade without direct interference of the politicians, while the LRT Law is repeatedly mentioned by the European Union as one of the most modern and best ensuring the independence of PSB from direct influence of politicians. The Council warned that the amendments under drafting would essentially mean the return to the model of state radio and television, while the LRT would become a mouthpiece of the ruling majority. The Council has criticised the linkage of the Council members' appointment with the political terms of office, and the possibility of LRT management crisis in case the Seimas fails to approve the LRT Council report (followed by necessity for the Director General to resign). The Council also questioned the right of institutions and organisations to recall members of the Council, the right of the authorized Seimas committee to approve or reject the strategy of LRT programmes. The contents of the submitted amendments, in the LRT Council opinion, contradicted the fundamental precepts of the democratic Europe, leading to nationalisation of the public service broadcaster and preparing the ground for anti-democratic processes as well as restriction of freedom of expression in Lithuania [48].

The concerns on the above-referred amendments have also been expressed by Ingrid Deltenre, Director General of the European Broadcasting Union (EBU). She criticised the intentions of changing the public Council composition, introducing the possibility of recalling the Director General by simple majority of votes, as well as interference by the Seimas in regulation of the programmes' content. It was forecasted that prohibition of advertising may disrupt activities of the LRT, causing failure to ensure sufficient independence of the broadcaster from the state institutions $[49 ; 50]$. Conclusions by Legal Department of the Seimas drew attention to the provisions that were in potential contradiction to the applicable laws (sole responsibility of Chairman of the LRT Council for actions of the collegial management body; legally questionable linkage of the employment contract of the LRT Director General to the accomplishment of annual plans [47]. Public resistance and the international opinion prevented from adopting such anti-democratic laws, and revising the public service broadcasting regulation procedure.

The preservation of the established model of the LRT management was followed by development of new financing model in 2014 [51]. Starting with the 1st January 2015, the LRT discontinued broadcasting the commercial ads, except for some cases (advertised culture and sport events, sponsorship or support notifications, and social advertising). Financing was linked to the state budget indicators ( 1.5 percent from the state and municipal budget revenues of a preceding 
year and 1.3 percent from the excise duty revenues) [51]. The LRT financing became independent from the executive authorities and is known in advance (calculated under the fixed formula (e.g. for the year 2015, under the budget revenue and excise duty collection results of 2013; for the year 2016, under results of 2014, etc.).

\section{Conclusions}

The approach to the national public service broadcaster evidences the maturity of the state and the civil society. Often, politicians pursue retaining their influence and leverage on the mass media, while intellectuals are not shying away from serving the policymakers in their political games. Opportunities to adequately exercise functions of the public service broadcasting are secured by the independency from the ruling majority deriving from the independent financing and independent governance by the public representatives.

The history of Lithuanian audio-visual broadcasting stretches back to the 20th century. The Lithuanian Radio began its broadcastings in 1926, while the Lithuanian Television commenced its activities in 1957. After declaration of the independence (the 11th March 1990), Lithuania started pursuing introduction of the Western model of public service broadcasting. The Supreme Council - Re-constituent Seimas has reorganized the soviet propaganda institution into an independent Lithuanian broadcaster (LRT). Following the new LRT Statute, radio and television became an institution accountable to the Parliament and led by the public institution, i.e. the LRT Managing Board. Nevertheless, significant influence of policymakers remained, i.e. Board members were appointed for the period of the Seimas mandate, and the Parliament members had an exclusive right to use LRT airtime.

In 1996, Lithuania adopted significant documents regulating the media services, i.e. Law on Provision of Information to the Public and Law on the National Radio and Television. The LRT Managing Board was replaced by the Council of 13 members ( 3 appointed by the President, 4 appointed by the Seimas, and 6 members delegated, as drawn by lot, by nine public organisations). It was decided to collect a subscription fee to finance the LRT, reducing commercial ads and budget allocations, though such provision has not been implemented.

Later the attempts of exerting influence on the LRT have been made on several occasions. Despite of the official declarations about further limiting the interference with the national service broadcaster, there actually were the attempts of greater influence and politicisation.

Politicisation by depoliticising. In pursuit of changing the LRT management the procedure of LRT Council formation was changed in 1996-1997: representatives were delegated by 15 creative and public organisations. The principles of public organisations selection have been criticised.

Politicisation by de-commercialising. In 2000-2002, the LRT was criticised because of its commercialisation and non-performance of its mission. It was intended to develop a special funding system whereby the LRT should submit the Seimas with a funding plan and evidences justifying that the anticipated programmes are in compliance with the national mission. Introduction of such amendments could pose a risk of direct political interference with the LRT management and formation of the programme content.

Politicisation by optimising. In 2009-2010 the attempts were made to radically reform the LRT management. Such pursuit faced resistance not only in Lithuania, but also caused considerable concern on the international level. The criticism related to linkage of the LRT Council members mandate with the political calendar, possibility of recalling the Council members by the delegating institutions and organisations, and the right of the Seimas Committee to approve or reject the strategy of the LRT programming.

In 2014, a new financing model of the LRT has been developed, following which the LRT in 2015 discontinued broadcasting the commercial ads (except for certain established cases). The 
LRT financing is known in advance and calculated on the basis of the budget revenue and excise duty collection results of a preceding calendar year.

\section{References}

1. Habermas, J. (1989), The Structural Transformation of the Public Sphere: An Inquiry into a Category of Bourgeois Society (reprint), Polity Press, Cambridge.

2. Habermas, Jurgen, (1978), L`Espace public. Archeologie de la publicite comme dimension constitutive de la societe bourgeoise, Payot, Paris.

3. Norris, P. (2000), Virtous Circle: Political Communication in Post-Industrial Societes, CU Press, Cambridge.

4. Miege, B. (1995), "L’espace public: au-de la sphere politique", Hermes, pp. 49-61.

5. De Proost, S. (2005), "Nouvel espace public, nouvel legitimite. Une television sans espace public?", MediaMorphoses, hors serie, pp. 95-99.

6. Albert, P. \& Leteinturier, C. (1999), Les medias dans le monde: enjeux et diversites nationales, Elipses, Paris.

7. Mescheriakoff, A.S. (2001), Droit de services publics, Presses Universitaires, Paris.

8. Lamizet, B. (1999), Histoire des medias audiovisuals, Elipses, Paris.

9. Albert, P. \& Tudesq, A.-J. (1986), Histoire de la radiotelevision, PUF, Paris.

10. Miguel, P. (1984), Histoire de la radio et de la television, Librairie academique, Paris.

11. Emery, W. (1969), National and International Systems of Broadcasting, Michigan State University Press, East Lansing.

12. Montagne, J.C. (1995), Histoire des moyens de telecommunication, PUF, Paris.

13. Ojalvo, A. (1993), La Grande Bretagne et sa television, Champ Vallon, Paris.

14. Bittner, J. (1991), Broadcasting and Telecomunication: An Introduction, Pentise Hall, Englewood Cliffs.

15. Chevalier, J. (1995), "Genese et actualite du service public", Dossiers de l'audiovisuel, no. 60.

16. Missika, J.L. (1999), "Retour sur la notion de service public", Dossiers de l'audiovisuel, no. 87.

17. Atkinson, D. (1999), "La TV publique a l'ere de la concurrence", Dossiers de l'audiovisuel, no. 87.

18. Atkinson, D. \& Raboy, M. (1997), “La radiotélévision de service public: les défis du XXI e siècle", Etudes et documents sur la communication, UNESCO.

19. Rumphorst, W. (2003), Model Public Service Broadcasting Law vith An Introductory Note and Explanatory Comments, ITU, BDT, UNESCO, Geneve.

20. The European Broadcasting Union (1996), Recommendation No. R (96) 10 of the Committee of Ministers to Member States on the Guarantee of the Independence of Public Service Broadcasting, 11 September 1996, available at: https://www.ebu.ch/files/live/sites/ebu/files/ Publications/Reference $\% 20$ texts/CoE\%20-\%20Media\%20Freedom\%20and\%20Pluralism/REF\% 20COE-CM\%20R(96)10.pdf (accessed 12 November 2015).

21. Musso, P. (2005), "Trois scenarios pour le service public", MediaMorphoses, hors series, pp. 59-65.

22. Cluzel, J. (1999), "Le financement du secteur public de l'audiovisuel", Dossiers du l'audiovisuel, no. 87.

23. Bourdon, J. (2005), “Quois de neuf dans le crise?”, MediaMorphoses, hors serie, pp. 913.

24. Legendre, P. (1976), Jouir du puovoir. Traite de la boureaucratie patriote, Editions de Minuit, Paris. 
25. Murdock, G. (1992), “Citizens, Consumers and Public Culture”, Medias Cultures: Reappraising Transnational, Routledge, London, pp. 17-41.

26. Jacka, E. (2003), "Democraty as Defeat. The impotence of Arguments for Public Service Broadcasting", Television and New Media, vol. 4, no. 2, pp. 177-191.

27. Garnham, N. (1990), Capitalism and Communication, Sage, London.

28. Cintra-Tores, E. (2005), "Un point de vue portugais", MediaMorphoses, hors serie, pp.151-157.

29. Ibanez, J.C. (2005), "Espagne: climat de crise, vent de reforme”, MediaMorphoses, hors series, pp. 125-130.

30. Stikelis, S. (1983), Radijas ir televizija, Informacinis zinynas, Vilnius.

31. The European Parliament (1997), Treaty of Amsterdam Amending the Treaty on European Union, the Treaties Establishing the European Communities and Certain Related Acts, available at: http://www.europarl.europa.eu/topics/treaty/pdf/amst-en.pdf (accessed 12 November 2015).

32. Brants, K. \& Siune, K. (1992), "Public Broadcasting is a State of Flux", Dynamics of Media Politics: Broadcast and Electronic Media in Western Europe, Sage, London, pp. 101-105.

33. Lietuvos Respublikos Seimas (1990), Statute of Radio and Television of Lithuania, available at: http://www3.1rs.lt/pls/inter3/dokpaieska.showdoc_1?p_id=208 (accessed 12 November 2015).

34. Lietuvos Respublikos Seimas (1990), Parliament debate transcript, available at: http://www3.lrs.lt/pls/inter3/dokpaieska.showdoc_1?p_id=251300 (accessed 12 November 2015).

35. Lietuvos Respublikos Seimas (1990a), Parliament debate transcript, available at: http://www3.lrs.lt/pls/inter3/dokpaieska.showdoc_1?p_id=251006 (accessed 12 November 2015).

36. Lietuvos Respublikos Seimas (1992), Parliament debate transcript, available at: http://www3.lrs.lt/pls/inter3/dokpaieska.showdoc_1?p_id=251187 (accessed 12 November 2015).

37. Lietuvos Respublikos Seimas (1996), Republic of Lithuania Law on Provision of Information to the Public, available at: http://www3.lrs.lt/pls/inter3/dokpaieska.showdoc_1? p_id=286382 (accessed 12 November 2015).

38. Lietuvos Respublikos Seimas (1996), Law on the National Radio and Television, available at: http://www3.lrs.lt/pls/inter3/dokpaieska.showdoc_1?p_id=240843\&p_tr2=2\#zyma_ 9s14poradijatv (accessed 12 November 2015).

39. Lietuvos Respublikos Seimas (1995), Parliament debate transcript, available at: http://www3.lrs.lt/pls/inter3/dokpaieska.showdoc_l?p_id=239970 (accessed 12 November 2015).

40. Lietuvos Respublikos Seimas (1995a), Parliament debate transcript, available at: http://www3.lrs.lt/pls/inter3/dokpaieska.showdoc_1?p_id=239040\#zyma_5s57podir (accessed 12 November 2015).

41. Council of Europe (1994), "The Media in a democratic society", Political Declaration, Resolutions and Statement, 4th Ministerial Conference: Mass Media Policy, Prague, 7-8 December 1994, MCM (94)20.

42. Jackunas, Z. (1998), “Amzinas įtampos laukas”, Kalba Vilnius, no. 10, p. 2.

43. Lietuvos Respublikos Seimas (1996), Parliament debate transcript, available at: http://www3.lrs.lt/pls/inter3/dokpaieska.showdoc_1?p_id=234542 (accessed 12 November 2015).

44. Open Society Foundations (2008), Television Across Europe: More Channels, Less Independence. Monitoring Report, Open Society Institut, Budapest, New York, available at: https://www.opensocietyfoundations.org/sites/default/files/1fullpublication_20080429_0.pdf (accessed 12 November 2015).

45. Lietuvos Respublikos Seimas (2002), Parliament debate transcript, available at: http://www3.lrs.lt/pls/inter3/dokpaieska.showdoc_1?p_id=188323 (accessed 12 November 2015).

46. Lietuvos Respublikos Seimas (2010), Parliament debate transcript, available at: http://www3.lrs.lt/pls/inter3/dokpaieska.showdoc_l?p_id=363951 (accessed 12 November 2015). 
47. Lietuvos Respublikos Seimas (2011), Parliament debate transcript, available at: http://www3.lrs.lt/pls/inter3/dokpaieska.showdoc_1?p_id=396928\&p_tr2=2 (accessed 12 November 2015).

48. Lietuvos žurnalistų sajunga (2010), "LRT taryba išplatino viešą pareiškimą dėl skubotų įstatymo pataisų”, available at: http://www.lzs.lt/lt/naujienos/ziniasklaida_lietuvoje/archyvas/ p90/lrt_taryba_isplatino_viesa_pareiskima_del_skubotu_istatymo_pataisu. $\overline{h t m l}$ (accessed 12 November 2015).

49. Deltenre, I. (2010), "Europos transliuotojai gina LRT teise gauti pajamu is reklamos", available at: http://m.lrytas.lt/-12638203761262416693-p1-europos-transliuotojai-gina-lrtteis $\%$ C4\%99-gauti-pajam\%C5\%B3-i\%C5\%A1-reklamos.htm (accessed 12 November 2015).

50. Nord, L. \& Glowacki M. (2010), "Public Service Media on the Baltic: The Role of the State? in Central and Northern European Media Systems. Special Issue", Central European Journal of Communication, vol. 3, no. 4.

51. Lietuvos Respublikos Seimas (2014), Law on the National Radio and Television, available at: http://www3.lrs.lt/pls/inter3/dokpaieska.showdoc_1?p_id=471236 (accessed 12 November 2015). 